\title{
DETECTION OF SOME VIRULENCE GENES IN SALMONELLA SPECIES ISOLATED FROM DUCKS AND DUCK EGGS
}

\author{
EL-GAOS, M.I.; KHALIL, M.R. AND GHADA ALLAM ABD EL-DAYEM \\ Poultry Diseases Dept., Animal Health Research Institute, Mansoura
}

Received: 29 October 2019; Accepted: 26 November 2019

\begin{abstract}
Four hundred and fifty (450) samples were collected, 200 from internal organs (liver, caecum, gall bladder and spleen) of 50 ducks, 200 from internal organs of 50 ducklings and 50 unhatched duck eggs (dead in shell embryo) from different farms and hatcheries in Dakahlia Province. All samples were cultured on specific media for isolation and serological identification of Salmonellae spp. A total of 71 samples were positive to Salmonella with total percentage (15.8\%). 29, 37 and 5 with $(14.5 \%, 18.5 \%$ and $10 \%)$ positive samples were isolated from ducks, ducklings and duck eggs, respectively. Serotyping of the isolated Salmonellae from ducklings were five S.infantis, four S.kentucky, ten S.typhimurium, six S.newport, six S.enteritidis and six untypeable Salmonella with a percentage of $(13.5 \%),(10.8 \%),(27 \%),(16.2 \%),(16.2 \%)$ and $(16.2 \%)$, respectively. Three $S$. derby, six S.typhimurium, five S.kentucky, three $S$. shubra, four $S$. enteritidis, three S.newport and five untypeable Salmonella were isolated from ducks with a percentage of (10.3\%), (20.7\%), (17.2\%), (10.3\%), (13.8\%), $(10.3 \%)$ and $(17.2 \%)$, respectively. On the other hand only one of each S.typhimurium, S. enteritidis, S. newport, S. infantis and untypeable Salmonella were isolated from duck eggs with a percentage of (20\%) for each one of these isolates. S.typhimurium was the most prevalence isolates and showed high resistance to streptomycin $(100 \%)$, lincomycin $(88 \%)$, erythromycin $(82 \%)$, oxytetracycline $(76 \%)$ and trimethoprim-sulfamethoxazole $(70 \%)$. Moderate resistance to neomycin (59\%), gentamycin (59\%), amoxicillin (53\%), ampicillin (53\%) and chloramphenicol $(47 \%)$ we reported. Meanwhile, the lowest resistances were against doxycycline $(41 \%)$, flumequine (35\%), norfloxacin (18\%), ciprofloxxacin (6\%) and colistin (6\%). Conventional PCR assay detected virulence genes (invA, $m g t \mathrm{C}$, $\operatorname{sop} \mathrm{B}$ and $b c f \mathrm{C})$ using specific primer for each gene in all examined S.typhimurium samples. This study highlights that, there was significant association between $\operatorname{inv} \mathrm{A}, m g t \mathrm{C}, \operatorname{sop} \mathrm{B}$ and $b c f \mathrm{C}$ virulence genes and pathogenicity of S.typhimurium which showed high multiple antibiotic resistance which require strict regulations of the use of antibiotics in duck farms to minimize the resistant bacterial strains.
\end{abstract}

Key words: PCR, duck, virulence genes, S.typhimurium, antibiotic resistance.

\section{INTRODUCTION}

Salmonellosis is a zoonotic bacterial disease of national and international importance. The worldwide distribution of Salmonellosis often parallels the patterns of trade of animal products and food, and the migration patterns of human and animals (Gilbert et al., 2010).

Avian Salmonellosis is an important disease causing serious impediment to the development of poultry industry especially in developing countries of Asia and Africa. Since no "effective" immuno-prophylactic measures are available for the disease till now, strict biosecurity is the only alternative to preclude the disease (Rajagopal et al., 2013).

Corresponding author: EL-GAOS, M.I

E-mail address: elgaos122@gmail.com

Present address: Poultry Diseases Dept., Animal Health Research Institute, Mansoura
The pathogenicity of Salmonella depends on a series of factors associated with the bacterium, the bird itself and the conditions in which the bird is raised. Attachment and penetration of the bacterium into digestive mucosa is a prerequisite for systemic infection (Rychlik et al., 1999). Polymerase chain reaction (PCR) is molecular biology technique which has taken up an increasingly significant space in the field of laboratory diagnostics, allowing the detection of various pathogens such as Salmonella species in different kinds of food. PCR can reduce the time required to detect and identify the agent with high specificity and sensitivity (Santos et al., 2001).

Most bacterial pathogens including pathogenic Salmonella species have multiple virulence properties that enable them to invade and survive within the host and ultimately cause a disease (Marcus et al., 2000).

Detection and monitoring of drug-resistant Salmonella are important to substantiate the choice of antibiotics for the treatment of clinical Salmonellosis 
and to assess the risk of exposure of multiple drug resistant strains (Yang et al., 2002).

This study was planned to estimate the prevalence of salmonella serovars implicated in the majority of infection in ducks and duck eggs and to determine some virulence genes associated with $S$. typhimurium infection in addition to study antimicrobial resistance profile that help to reduce the spread of resistant salmonella among the diseased ducks via planning a proper control program.

\section{MATERIALS AND METHODS}

\section{Samples:}

A total number of (450) samples from ducklings, ducks and duck eggs were collected as shown: (200) ducklings samples from internal organs (liver, caecum, gall bladder and spleen) of (50) ducklings, 13 weeks old (freshly dead, diseased living and apparently healthy birds), (200) ducks samples from internal organs (liver, caecum, gall bladder and spleen) of (50) ducks (freshly dead, diseased living and apparently healthy birds) and (50) unhatched duck eggs (dead in shell embryo). All samples were obtained from different duck farms and hatcheries located in Dakahlia Governorate under aseptic condition in ice box and transferred to the laboratory. Collected samples were cultured within a limit time.

\section{Clinical and Postmortem examination:}

All birds were examined clinically, then sacrificed and immersed in disinfectant before being autopsied. Gross pathological changes were recorded, summarized and presented with results for both freshly dead and clinically sick ducks.

\section{Isolation of salmonellae:}

The collected samples were transferred to test tubes containing Tryptose broth and Selenite F-broth and incubate at $37{ }^{\circ} \mathrm{C}$ for $18-24$ hours, followed by subculturing on blood agar, MacConkey's agar and Xylose lysine desoxycholate agar plates and incubated aerobically at $37{ }^{\circ} \mathrm{C}$ for $18-24$ hours ISO 6579 (2002).

\section{Biochemical identification of the isolates:}

The growing colonies on various plates were examined morphologically, culturally and biochemically (Indole, Nitrate Reduction, Voges Proskaur, Citrate Utilization, Urease, Sugar Fermentation and Coagulase test) Quinn et al. (2002).

\section{Serological identification of salmonellae:}

Serological identification of purified strains of Salmonella using available agglutinating Salmonella test sera (Denken Selken Co. LTD, Tokyo, Japan) according to Kauffmann (1973).

PCR technique for detection of virulence genes (Oliveira et al., 2003):

PCR test was carried out for seven S.typhimurium samples in PCR unit in Animal Health Research Institute, AHRI for detection of virulence genes. PCR amplification kit the QIAamp®DNA Mini Kit (Cat. No. 51304-Qiagen) was used according to manufacturer's instructions.

\section{DNA extraction:}

Chromosomal DNA extraction from samples was performed using the QIAamp DNA Mini kit (Qiagen, Germany, GmbH) with modifications from the manufacturer's recommendations. Briefly, $200 \mu \mathrm{l}$ of the sample suspension was incubated with $10 \mu \mathrm{l}$ of proteinase $\mathrm{K}$ and $200 \mu \mathrm{l}$ of lysis buffer at $56^{\circ} \mathrm{C}$ for 10 min. After incubation, $200 \mu \mathrm{l}$ of $100 \%$ ethanol was added to the lysate. The sample was then washed and centrifuged following the manufacturer's recommendations. Nucleic acid was eluted with $100 \mu 1$ of elution buffer provided in the kit.

\section{Oligonucleotide Primer:}

Primers used were supplied from Metabion (Germany) are listed in Table (1).

\section{PCR amplification:}

Primers were utilized in a $25-\mu 1$ reaction containing $12.5 \mu \mathrm{l}$ of Emerald Amp Max PCR Master Mix (Takara, Japan), $1 \mu \mathrm{l}$ of each primer of $20 \mathrm{pmol}$ concentration, $4.5 \mu \mathrm{l}$ of water, and $6 \mu \mathrm{l}$ of DNA template. The reaction was performed in a T3 Biometra thermal cycler.

\section{Analysis of the PCR Products:}

The products of PCR were separated by electrophoresis on $1.5 \%$ agarose gel (Applichem, Germany, GmbH) in $1 \mathrm{x}$ TBE buffer at room temperature using gradients of $5 \mathrm{~V} / \mathrm{cm}$. For gel analysis, $20 \mu \mathrm{l}$ of the products was loaded in each gel slot. A gelpilot 100 bp DNA Ladder (Qiagen, Germany, GmbH) and generuler 100 bp ladder (Fermentas, Thermo) were used to determine the fragment sizes. The gel was photographed by a gel documentation system (Alpha Innotech, Biometra) and the data was analyzed through computer software. 
Table 1: Primers sequences, target genes, amplicon sizes and cycling conditions.

\begin{tabular}{|c|c|c|c|c|c|c|c|c|}
\hline \multirow[b]{2}{*}{$\begin{array}{l}\text { Target } \\
\text { gene }\end{array}$} & \multirow{2}{*}{$\begin{array}{c}\text { Primers } \\
\text { sequences }\end{array}$} & \multirow{2}{*}{$\begin{array}{l}\text { Amplified } \\
\text { segment } \\
\text { (bp) } \\
\end{array}$} & \multirow{2}{*}{$\begin{array}{c}\text { Primary } \\
\text { denaturation }\end{array}$} & \multicolumn{3}{|c|}{ Amplification (35 cycles) } & \multirow[b]{2}{*}{$\begin{array}{c}\text { Final } \\
\text { extension }\end{array}$} & \multirow[b]{2}{*}{ Reference } \\
\hline & & & & $\begin{array}{c}\text { Secondary } \\
\text { denaturation }\end{array}$ & Annealing & Extension & & \\
\hline invA & $\begin{array}{c}\text { GTGAAATTATC } \\
\text { GCCACGTT } \\
\text { CGGGCAA } \\
\text { TCATCGCA } \\
\text { CCGTCAAAGG } \\
\text { AACC } \\
\end{array}$ & 284 & $\begin{array}{c}94^{\circ} \mathrm{C} \\
5 \mathrm{~min} .\end{array}$ & $\begin{array}{c}94^{\circ} \mathrm{C} \\
30 \mathrm{sec} .\end{array}$ & $\begin{array}{c}55^{\circ} \mathrm{C} \\
30 \mathrm{sec} .\end{array}$ & $\begin{array}{c}72^{\circ} \mathrm{C} \\
30 \mathrm{sec} .\end{array}$ & $\begin{array}{c}72^{\circ} \mathrm{C} \\
10 \mathrm{~min}\end{array}$ & $\begin{array}{c}\text { Oliveira } \\
\text { et al., } \\
2003\end{array}$ \\
\hline $\operatorname{sop} B$ & $\begin{array}{c}\text { TCA GAA } \\
\text { GRCGTC } \\
\text { TAACCA CTC } \\
\text { TAC CGT CCT } \\
\text { CAT } \\
\text { GCA CAC TC }\end{array}$ & 517 & & & \multirow{3}{*}{$\begin{array}{c}58^{\circ} \mathrm{C} \\
40 \mathrm{sec} .\end{array}$} & & & \multirow{4}{*}{$\begin{array}{l}\text { Huehn } \\
\text { et al. } 2010\end{array}$} \\
\hline & $\begin{array}{c}\text { TGA CTA TCA } \\
\text { ATGCTC CAG } \\
\text { TGA AT } \\
\end{array}$ & & $94^{\circ} \mathrm{C}$ & $94^{\circ} \mathrm{C}$ & & & $72^{\circ} \mathrm{C}$ & \\
\hline$m g t C$ & $\begin{array}{c}\text { ATT TAC TGG } \\
\text { CCGCTA TGC } \\
\text { TGT TG } \\
\end{array}$ & 677 & $5 \mathrm{~min}$. & $30 \mathrm{sec}$. & & & $\begin{array}{c}35 \\
\text { Sec. }\end{array}$ & \\
\hline$b c f C$ & $\begin{array}{c}\text { Acc Aga Gac Att } \\
\text { Gcc } \\
\text { Ttc C } \\
\text { Ttc Tgc Tcg Ccg } \\
\text { Cta } \\
\text { Ttc G }\end{array}$ & 467 & & & $\begin{array}{c}53^{\circ} \mathrm{C} \\
40 \mathrm{sec} .\end{array}$ & & & \\
\hline
\end{tabular}

In vitro antibiotic susceptibility test:

Seventeen S.typhimurium isolates were subjected to antibiotic sensitivity test against 15 commonly used antibiotics. The antimicrobial susceptibility profile against oxytetracycline, ampicillin, erythromycin, gentamycin, streptomycin, neomycin, lincomycin, chloramphenicol, ciprofloxacin, trimethoprimsulfamethoxazole, amoxicillin, doxycycline, flumequine, colistin and norfloxacin were tested by disk diffusion methods according to Clinical and Laboratory Standards Institute (CLSI, 2012).

\section{RESULTS}

Table 2: The prevalence of Salmonella species recovered from collected samples.

\begin{tabular}{cccccc}
\hline \multirow{2}{*}{ samples } & $\begin{array}{c}\text { Number of } \\
\text { examined } \\
\text { samples }\end{array}$ & $\begin{array}{c}\text { Rumber of } \\
\text { positive samples }\end{array}$ & $\%$ & $\begin{array}{c}\text { Number of negative } \\
\text { samples }\end{array}$ & $\%$ \\
\hline $\begin{array}{c}\text { Ducks } \\
\text { (internal organs) }\end{array}$ & 200 & 29 & 14.5 & 171 & 85.5 \\
\hline $\begin{array}{c}\text { Duckling } \\
\text { (internal organs) }\end{array}$ & 200 & 37 & 18.5 & 163 & 81.5 \\
\hline Duck eggs & 50 & 5 & 10 & 45 & 80 \\
\hline Total & 450 & 71 & 15.8 & 379 & 84.2 \\
\hline
\end{tabular}

Clinical and postmortem findings of examined birds:

The clinical signs observed on examined ducks suffered from salmonellosis were lowered heads, closed eyes, drooping wings, ruffled feathers, Whitish watery diarrhea, death, pasted vent, conjunctivitis, retarded growth and lameness.

The postmortem examination of both freshly dead and sacrificed ducks suffered from salmonellosis were unabsorbed yolk sac (ducklings), congested internal organs (Liver, kidney and spleen) with enlarged gall bladder, pinpoint necrotic foci on the bronzed liver, spleenomegaly with congested kidneys and white cecal core with enteritis. 
Table 3: Serotyping of the isolated Salmonella species.

\begin{tabular}{cccc}
\hline Isolated strains & Duckling, No. and $(\%)$ & Duck, No. and $(\%)$ & Duck eggs, No. and $(\%)$ \\
\hline S. Kentucky & $4(10.8 \%)$ & $5(17.2 \%)$ & $0(0 \%)$ \\
\hline S. Derby & $0(0 \%)$ & $3(10.3 \%)$ & $0(0 \%)$ \\
\hline S. Typhimurium & $10(27 \%)$ & $6(20.7 \%)$ & $1(\% 20)$ \\
\hline S. Newport & $6(16.2 \%)$ & $3(\% 10.3)$ & $1(\% 20)$ \\
\hline S. Enteritidis & $6(16.2 \%)$ & $4(13.8 \%)$ & $1(20 \%)$ \\
\hline S. Infantis & $5(13.5 \%)$ & $0(\% 0)$ & $0(0 \%)$ \\
\hline S. Shubra Sh & $0(0 \%)$ & $3(\% 10.3)$ & $1(\% 20)$ \\
\hline Untyped salmonella & $6(16.2 \%)$ & $5(17.2 \%)$ & $5(100 \%)$
\end{tabular}

\section{S. typhimurium was the most prevalence isolates}

Table 4: Antibiotic sensitivity and resistance pattern for (17) S.typhimurium isolates.

\begin{tabular}{|c|c|c|c|c|c|}
\hline \multirow{2}{*}{ Antibiotic } & \multirow{2}{*}{ Antimicrobial class } & \multicolumn{2}{|c|}{ Sensitive } & \multicolumn{2}{|c|}{ Resistant } \\
\hline & & No. & $(\%)$ & No. & $(\%)$ \\
\hline Streptomycin & Aminoglycosides & 0 & 0 & 17 & 100 \\
\hline Lincomycin & Lincosamides & 2 & 12 & 15 & 88 \\
\hline Erythromycin & Macrolydes & 3 & 18 & 14 & 82 \\
\hline Oxytetracycline & Tetracycline & 4 & 24 & 13 & 76 \\
\hline $\begin{array}{l}\text { Trimethoprim- } \\
\text { sulfamethoxazole }\end{array}$ & Sulphonamides & 5 & 30 & 12 & 70 \\
\hline Gentamycin & Aminoglycosides & 7 & 41 & 10 & 59 \\
\hline Neomycin & Aminoglycosides & 7 & 41 & 10 & 59 \\
\hline Ampicillin & B- Lactam & 8 & 47 & 9 & 53 \\
\hline Amoxicillin & B -Lactam & 8 & 47 & 9 & 53 \\
\hline Chloramphenicol & Phenicols & 9 & 53 & 8 & 47 \\
\hline Doxycycline & Tetracyclines & 10 & 59 & 7 & 41 \\
\hline Flumequine & $\begin{array}{c}1^{\text {st }} \text { Generation } \\
\text { Quinolones }\end{array}$ & 11 & 65 & 6 & 35 \\
\hline Norfloxacin & $\begin{array}{c}2^{\text {nd }} \text { Generation } \\
\text { Quinolones }\end{array}$ & 14 & 82 & 3 & 18 \\
\hline Colistin & Peptides & 16 & 94 & 1 & 6 \\
\hline Ciprofloxacin & $\begin{array}{c}2^{\text {nd }} \text { Generation } \\
\text { Quinolones }\end{array}$ & 16 & 94 & 1 & 6 \\
\hline
\end{tabular}

Table 5: Result of PCR assay for detection of virulence genes of S. typhimurium.

\begin{tabular}{ccccc}
\hline & \multicolumn{5}{c}{ Results } \\
\cline { 2 - 5 } Sample & invA & mgtC & sopB & bcfC \\
\hline 1 & + & + & + & + \\
\hline 2 & + & + & + & + \\
\hline 3 & + & + & + & + \\
\hline 4 & + & + & + & + \\
\hline 5 & + & + & + & + \\
\hline 6 & + & + & + & + \\
\hline 7 & + & + & + &
\end{tabular}




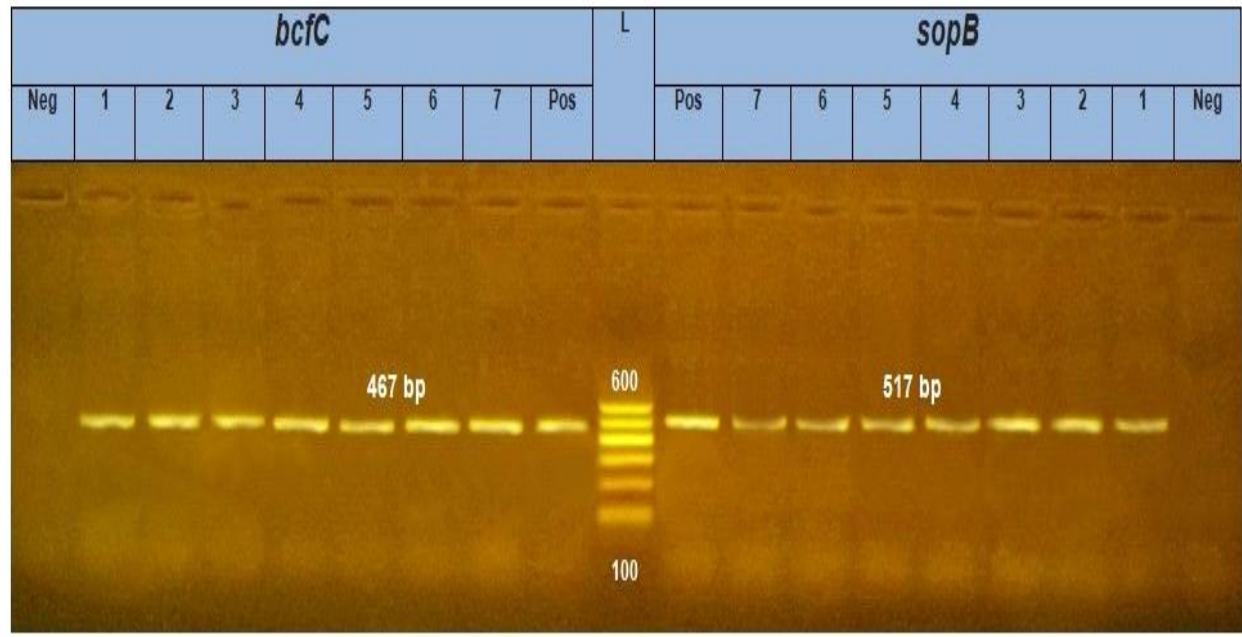

Figure (1): Agarose gel electrophoresis showing amplification of 467bp fragment using bcfc primer and 517 bp L: $100-600$ bp ladder. fragment using sopB primer.

Lane (1-7): positive samples.

Neg: negative

Pos: positive

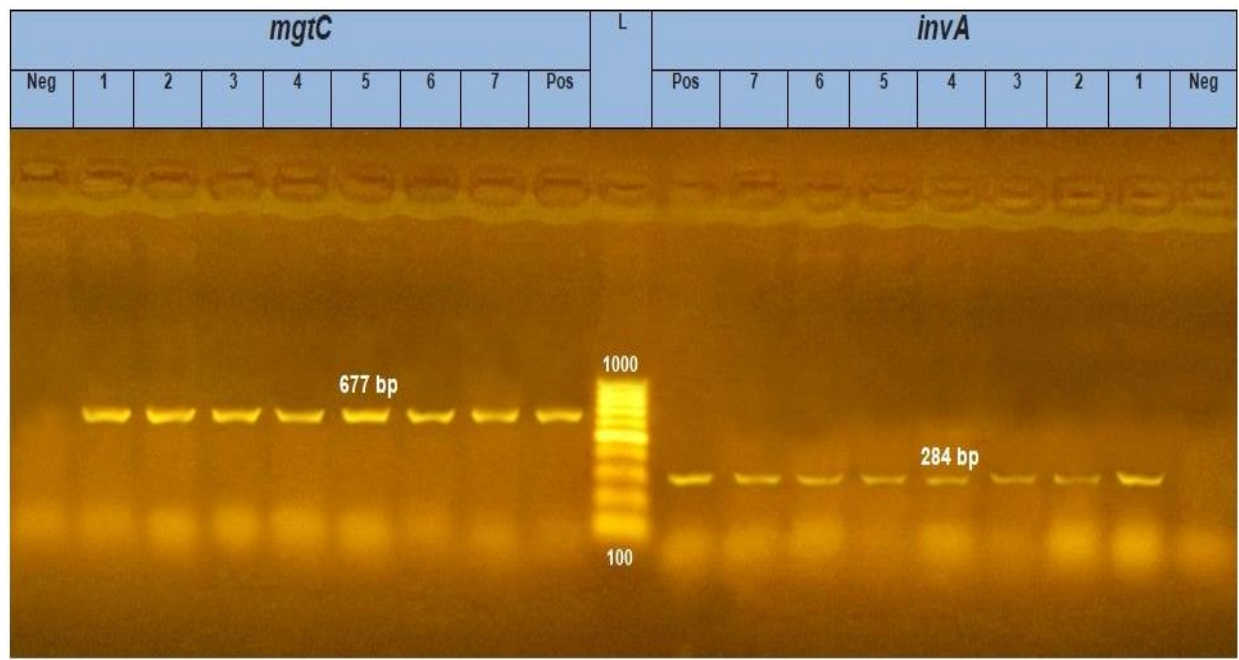

Figure (2): Agarose gel electrophoresis showing amplification of 677bp fragment using mgtC primer and $284 \mathrm{bp}$ L: $100-1000$ bp ladder. fragment using invA primer.

Lane (1-7): positive samples.

Neg: negative

Pos: positive

\section{DISCUSSION}

Salmonella is one of the most important pathogen that can infect poultry and causing serious illness in human through consumption of contaminated food products. Egypt has experienced the repeated introduction and dissemination of a wide range of Salmonella serotypes that have become a major concern for both human and animal health. Detection of Salmonellosis is considered a good tool in protection of poultry industry FAO (1994). Further more, Salmonella infection is one of the most important bacterial diseases in poultry causing heavy economic loss through mortality and reduced production Haider et al. (2004).

The present investigation revealed that the clinical signs of salmonellosis in ducks were lowered heads, closed eyes, drooping wings, ruffled feathers, whitish watery diarrhea, death, pasted vent, lameness and conjunctivitis. These findings are in agreement with those observed by Riberio et al. (2005).

Postmortem lesions of salmonellosis recorded in ducks were unabsorbed yolk sac, congested internal organs, pinpoint necrotic foci on the liver with bronze discoloration, spleenomegaly with congested kidneys 
and white cecal core. These findings are similar with those observed by Saif et al. (2008).

In our study 71 out of 450 samples from ducklings, ducks and duck eggs were found to be positive to Salmonella (15.8\%) as shown in table (2). This result was in agreement with that of Lam et al. (2002) and Nayera (2012) who reported (12.7\%) and (14.42\%), respectivily. Meanwhile, Asawy and Abd El-latif (2010) reported (3.3\%) and Abd El-Tawab et al. (2015) reported $(9.6 \%)$. Twenty nine samples from ducks were found to be positive with a percentage of $(14.5 \%)$. This finding was in accordance with that of Mondai et al. (2008) who recorded (13.07\%). On the other hand El-Zeedy et al. (2007) and Tasi and Hsing (2005) recorded $(7.8 \%)$ and $(4.6 \%)$ for Salmonella, respectivily.

In the current study 37 ducklings samples were found positive for Salmonella isolation at a percentage of $(18.5 \%)$. This result was in the same direction with Huang et al. (1994) who reported (19.3\%) and Lam et al. (2002) (18\%). This result disagreed with Osman et al. (2014) who reported $(12 \%)$. The prevalecce of isolation of Salmonella in ducklings $(18.5 \%)$ was higher than that in ducks $(14.5 \%)$. This was in accordance with that of Lam et al. (2002) and Tasi and Hsing (2005).

In we present study five duck eggs were positive for Salmonella isolation at rate of $(10 \%)$. This result agreed more or less with the results reported by Shareef et al. (1997) and Mohammed (2014) who reported a prevalence rate of $(8 \%)$ and $(9.09 \%)$, respectively. In the current study the isolated Salmonella serotypes from ducklings were S.kentuckey, S.infantis, S.typhimurium, S. newport and S.enteritidis as shown in Table (3) These findings were in agreement with that reported by El-Zeedy et al. (2007) who isolated S.enteritidis, S.typhimurium and S.infantis from ducklings. Meanwhile the isolated Salmonella serotypes from ducks were S.derby, S.newport S.typhimurium, S.kentucky, S.enteritidis and S.shubra. Similar results for serological identification were reported by Tasi and Hsing (2005) who isolated S.typhimurium, S.newport and S.derby from ducks. The isolated Salmonella from duck eggs were S.typhimurium, S.infants, S.enteritidis and S. newport. Mohammed (2014) was able to isolated S.typhimurium from duck eggs.

In the present study S. typhimurium was the most prevalence isolates. This might run parallel with Mituniewicz et al. (2007). But Hamad (2017) reported that S.enteritidis was the most prevalent isolates from ducks samples.

Regarding antibiotic sensitivity our study showed that S.typhimurium was highly resistant to streptomycin, lincomycin, erythromycin, oxytetracycline and trimethoprim-sulfamethoxazole in percentage of
$100 \%, 88 \%, 82 \%, 76 \%$ and $70 \%$, respectively as shown in table (4). This result nearly agreed with that recorded by Yoshida et al. (1993) who cited that Salmonella was resistant to oxytetracycline, streptomycin and trimethoprim-sulfamethoxazole and Oja and Adetosoye (2009) who reported that, S.typhimurium was resistant to erythromycin. In the present study S.typhimurium showed moderate resistance to neomycin (59\%), gentamycin (59\%), amoxicillin (53\%), ampicillin (53\%) and chloramphenicol (47\%). This is in agreement with Mondai et al. (2008) and Boris et al. (2012). The highest sensetivity rates were $(59 \%, 65 \%, 82 \%, 94 \%$ and $94 \%$ ) for doxycycline, flumequine, norfloxacin, ciprofloxacin and colistin, respectively. This was in the same direction with Chashni et al. (2009) who reported that the sensitivity rates of S.typhimurium were to flumequine (74\%) and norfloxacin (93\%), Abd El-Hamid et al. (2003) norfloxacin (86.96\%) and Nagappa et al. (2007) showed that colistin was highly effective aganist S.typhimurium. On the other hand Cardoso et al. (2006) reported that S.typhimurium was resistant to colistin.

Amplification of invA gene now has been recognized as an international standard for detection of Salmonella genus Malorny et al. (2004). The invA gene encodes a protein in the inner membrane of bacteria, which is necessary for invasion to the epithelial cells of the host Darwin and Miller (1999). Development of a PCR system remains a suitable molecular tool to diagnose Salmonella on the basis of invA amplification and this has been reported by BisiJohnson et al. (2011).

In the present study, PCR assay was carried out for the detection of the invA gene from the isolated strains. The result revealed that the gene was present in all of the isolates $(100 \%)$ that was demonstrated by the presence of 284 bp PCR amplified fragment which agreed with Dione et al. (2011).

Concerning $b c f C$ gene (fimberial gene) code for an outer membrane usher protein, which carried in the microbial genome as part of a transposable element allowing a better bacterial protein secretion during the intestine invasion and present in all strains with (100\%).This result agreed with that of Nayera (2012) who present it in almost strains $(95.7 \%)$. Regarding sop B gene encodes an inositol phosphate phosphatase that is transported into epithelial cells by the SPI-1 secretion system and indirectly affects chloride secretion by inositol phosphate signaling pathways. PCR assay was carried out for the detection of the sop B gene from the isolated strains. The result revealed that the gene was present in all of the isolates $(100 \%)$. This was in accordance with that of Mohammed (2014). With respect to $m g t C$ gene is required for intra-macrophage survival and growth in magnesium-depleted medium and also is essential for organisms that invade host cells as cited by Alix and 
Blanc-Potard (2008), the $m g t \mathrm{C}$ gene was present in all examined isolates $(100 \%)$. This result was similar to that of Zou et al. (2012). In the same regard Nayera (2012) and Mohammed (2014) were able to find mgtC gene in $(54.3 \%)$ and $(53.3 \%)$ of examined strains, respectivily.

The current investigation concluded that, there was significant association between $i n v \mathrm{~A}, m g t \mathrm{C}, \operatorname{sop} \mathrm{B}$ and $b c f C$ virulence genes and pathogenicity of S.typhimurium which expresed high multiple antibiotic resistance which require strict regulations of using antibiotics in duck farms to minimize the resistant bacterial stranis.

\section{REFERENCES}

Abd El-Hamid, H.S.; He Gazy, A.M. and El-Lankany, H. (2003): Epidemiology of Salmonella in broiler chicken farms. The $3^{\text {rd }}$ International Conference, Mansoura, 29-30 April, 2003: 5589.

Abd El-Tawab, A.A.; Ammar, A.M.; Soad, A.N.; ElHofya, F.I. and Nabil, N.M. (2015): Studies on different Salmonella serotypes isolated from poultry in different Governorates in Egypt. Benha Vet. Med. J., 28,(2).169-175.

Alix, E. and Blanc-Potard, A.B. (2008): Peptideassisted degradation of the Salmonella $m g t C$ virulence factor. EMBO. J, 27, 546-557.

Asawy, A.M.E. and Abd El-Latif, M.M.A. (2010): Some bacteriological and serological studies on enteritis in ducks. Assiut Veterinary Medical Journal.56: 125, 239-249. 33 ref.

Bisi-Johnson, M.A.; Obi, C.L.; Vasaikar, S.D.; Baba, K.A. and Hattori, T. (2011): Molecular basis of virulence in clinical isolates of Escherichia coli and salmonella species from a tertiary hospital in the Eastern Cape, South Africa. Gut Pathogens, 3, 9.

Boris, H.; Borka, S.; Gordan, K. and Fani, K. (2012): Antimicrobial resistance and serotyping of Salmonella enterica subsp. enterica isolated from poultry in Croatia. Vet. arhive 82, 371-381, 2012.

Cardoso, M.O.; Ribeiro, A.R.; Santos, L.R.; Pilotto, F.; Moraes, H.S.; Salle, C.P.; Rocha, S.S. and Nascimento, V.P. (2006): Antibiotic resistance of Salmonella enteritidis isolated from broiler carcasses. Braz. J. Microbiol., 37: 368-371.

Chashni, E.; Hassanzadeh, M.; Fard, B. and Mirzaie, S. (2009): Characterization of the Salmonella Isolates from Backyard Chickens in North of Iran, by Serotyping, Multiplex PCR and Antibiotic Resistance Analysis. Archives of Razi Institute, Vol. 64, No. 2, $77-83$.

CLSI (2012): The Clinical and Laboratory Standards Institute: Methods for dilution antimicrobial susceptibility tests for bacteria that grow aerobically; approved standard. $9^{\text {th }}$ Edition. M07-A9, 32(2).
Darwin, K. and Miller, V. (1999): Molecular basis of the interaction of Salmonella with the intestinal mucosa. Clin Microbiol Rev. 12: 405 $-428$.

Dione, M.M.; Saha, D., Mohammed, N.I.; Adegbola, R.A.; Ieven, M. and Antonio, M. (2011): Antimicrobial resistance and virulence genes of non-typhoidal Salmonella isolates in The Gambia and Senegal. J. Infect. Dev. Ctries, 5, 765-775.

EL- Zeedy, S.A.; ELdeen, H.K. and Badr, G.M. (2007): Protein analysis for comparison between salmonellae isolated from different poultry species. BS. Vet. Med. J., 17 (2): 1-9.

Food Agriculture Organization / World and Heath Organization FAO / WHO (1994): Bacterial food borne illness costs in USA. Collaborating center for research and training in food hygiene and zoonoses, Berlin 1987. New sletter 23: 3.

Gilbert, S.; Lake, R.; Cressey, P.; Hudson, A. and King, N. (2010): Risk Profile Salmonella (Non Typoidal) in Pork and Pork Products, Institute of Environmental Science and Research Limited.

Haider, M.; Hossain, M.; Hossain, M., Chowdhury, E.; Das, P. and Hossain, M. (2004): Isolation and characterization of Enterobacteria Associated with Health and Disease in Sonali Chickens. Bangalladesh Journal of Veterinary Medicine. 2 (1):15 - 21.

Hamad, Enas, M.A. (2017): Current status of paratyphoid infection among birds. Ph.D. Thesis, Fac. Vet. Med.,Zagazig Univ.

Huang, B.K.; Xie, D.S. and Wang, H.Z. (1994): Diagnosis and control of Salmonellosis in ducklings.Chinese Journal of Veterinary Medicine. 20: 2, 9-11. 6 ref.

Huehn, S.; Ragione, R.M.; Anjum, M.; Saunders, M.; Woodward, M.J.; Bunge, C.; Helmuth, R.; Hauser, E.; Guerra, B.; Beutlich, J.; Brisabois, A.; Peters, T.; Svensson, L.; Madajczak, G.; Litrup, E.; Imre, A.; HerreraLeon, S.; Mevius, D.; Newell, D.G. and Malorny, B. (2010): Virulotyping and antimicrobial resistance typing of Salmonella enterica serovars relevant to human health in Europe. Foodborne Pathogens Dis 2010, 7: 523-35.

ISO 6579 (2002): Microbiology of food and animal feeding stuffs- horizontal method for the detection of salmonella species International standard. ( $4^{\text {th }}$ edition $)$.

Kauffmann, F. (1973): Serological diagnosis of Salmonella species. Kaufmann White Scheme, Copenhagen, Denmark.

Lam, N.D.; Anh, N.P.; Brugere-Picoux, J.; Bodin, G.; Tripodi, A. and Carles, M. (2002): Preliminary survey of the Salmonella infection in ducks in Can Tho province, Vietnam. Khoa Hoc Ky Thuat Thu Y (Veterinary Sciences and Techniques). 9: 1, 6-12. 
Malorny, B.; Paccassoni, E.; Fach, P.; Bunge, C.; Martin, A. and Helmuth, R. (2004): Diagnostic real-time PCR for detection of Salmonella in food. Appl. Environ. Microbiol. 12: 7046 - 52.

Marcus, L.; Brumell, J.; Pfeifer, C. and Finlay, B. (2000): Salmonella pathogenicity islands: big virulence in small packages. Microbes Infect. 2: $145-156$.

Mituniewicz, T.; Sowinska, J.; Iwanczuk-Czernik, K.; Witkowska, D.; Wojcik, A.; Kleinszmidt, K. and Sobczak, J. (2007): Salmonella bacteria occurrence on poultry farms in Warmia and Mazury province between 2001-2005. Medycyna Weterynaryjna. 63: 9, 1081-1083. 16 ref.

Mohammed, E.E.S. (2014): Studies on recent methods for detection of Salmonella species isolated from poultry. M.V.Sc., Thesis, Benha Univ.

Mondai, T.; Khan, M.S.R.; Alam, M.; Purakayastha, M.; Das, M. and Siddique, M.P. (2008): Isolation, identification and characterization of Salmonella from duck. Bangladesh Journal of Veterinary Medicine. 6: 1, 7-12. 8 ref.

Nagappa, K.; Tamuly, S.; Brajmadhuri, Saxena, M. and Singh, S. (2007): Isolation of Salmonella typhimurium from poultry eggs and meat of Tarai region of Uttaranchal. Indian Journal of Biotechnology Vol. 6, pp 407-409.

Nayera, M.M. (2012): Genomic comparison and characterization of Salmonella enterica serovars by the use of different molecular techniques. Ph.D. Thesis, Fac. Vet. Med., Cairo Univ, 266297.

Ojo, E. and Adetosoye, I. (2009): Salmonella typhimurium infection in diarrhoeic and nondiarrhoeic dogs in Ibadan, Nigeria. Veterinarski Arhiv 79 (4), 371 - 377.

Oliveira, S.D.; Rodenbusch, C.R.; Ce, M.C.; Rocha, S.L.S. and Canal, C.W. (2003): Evaluation of selective and non selective en-richment PCR procedures for Salmonella de-tection. Lett. Appl. Microbiol., 36: 217-221

Osman, K.M.; Marouf, S.H.; Zolnikov, T.R. and Al Atfeedy, N. (2014): Isolation and characterization of Salmonella enterica in day-old ducklings in Egypt. Pathogens and Global Health. 108 (1). $37-$ 48.

Quinn, P.J.; Markey, B.K.; Carter, M.E.; Donnelly, W. C. and Leonard, F.C. (2002): Veterinary Microbiology and Microbial Diseases. Salmonella serotypes. Great Britain by HPG, Books Ltd., Bodmin, Cornwall, UK. P.114-118.

Rajagopal,_R.; Mini, M. and Ramanathan, R. (2013): Outbreaks of salmonellosis in three different poultry farms of Kerala, India. Asian, Pac, J,
Trop, Biomed. 2013 Jun, 3(6): 496-500. Department of Veterinary Microbiology, College of Veterinary and Animal Sciences, Mannuthy, Thrissur, Kerala, India, 689521.

Ribeiro, S.A.M.; Berchieri, J.A.; Orsi, M.A.; Mendonça, A.O. and Ferrati A.R. (2005): Experimental infection by Salmonella enterica subsp enterica serovar Kottbus in day-old broiler chickens. Brazilian Journal Poultry Science; pp.107-112.

Rychlik, I.; Vankesteren, L.; Cardova, L.; Svestkova, A.; Martinkova, R. and Sisak, S. (1999): Rapid detection of Salmonella in field samples by nested polymerase chain reaction. Lett. Appl. Microbial.29: 269 - 272.

Saif, Y.M.; Fadly, A.M.; Glisson, J.R.; McDougald, L.R.; Nolan, L.K. and Swayne, D.E. (2008): Diseases of Poultry $12^{\text {th }}$ (Salmonella infection) Edition, Ed. Mosbay - Welfe.

Santos, L.R.; Nascimento, V.P.; Oliveira, S.D.; Flores, M.L.; Pontes, A.P.; Ribeiro, A.R.; Salle, C.T.P. and Lopes, R.F.F. (2001): Polymerase chain reaction (PCR) for the detection of Salmonella in artificially inoculated chicken meat, Review Inst. Medicine trop. S. Paulo, Vol. 43 No. 5, P. 247: 250.

Shareef, A.M.; Al-Sanjary, R.A. and Hassan, A.A. (1997): Recovery of two types of Salmonella from eggs of free range rearing hens and ducks. Ieaqi Journal of Vet. Sci. 1997, 10: 2; 125-128.

Tsai, H.J. and Hsiang, P.H. (2005): The prevalence and antimicrobial susceptibilities of Salmonella and Campylobacter in ducks in Taiwan. J Vet Med Sci. 67(1):7-12.

Yang, S.; Park, K.; Kim, K.; Besser, T.; Yoo, H.; Lee, B. and Park, Y. (2002): Antimicrobial resistance in Salmonella enterica serovars Enteritidis and Typhimurium isolated from animals in Korea: Comparison of phenotypic and genotypic resistance characterization. Vet. Microbial. 86: 295-301.

Yoshida, E.; Saitanu, K.; Jernklinchan, J.; Bangtra kulnonth, A.; Ingkaninun, $P$. and Poomivses, $P$. (1993): Comparison of drug resistance and conjugative $\mathrm{R}$ plasmids of Salmonella typhimurium isolated from humans and poultry. Proc., 11th Int. Symp. World Assoc.Vet. Food Hyg., Thailand, $561-567$.

Zou, M.; Keelara, S. and Thakur, S. (2012): Molecular characterization of Salmonella enterica serotype Enteritidis isolates from humans by antimicrobial resistanc, virulence genes and pulsed-field gel electrophoresis. Food Borne Pathogens and Diseases. 9. (3) 


\section{الكثف عن بعض جينات الضراوة للسالمونيلا المعزولة من البطوبيض البط}

\section{محد إبراهيم الجاعوص ، مصطفى ربيع ظليل ، غادة علام عبل الدايم}

E-mail: elgaos122@gmail.com Assiut University web-site: www.aun.edu.eg

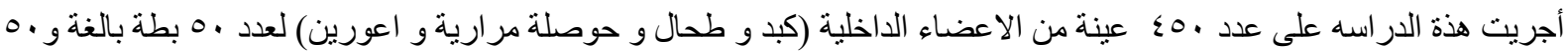

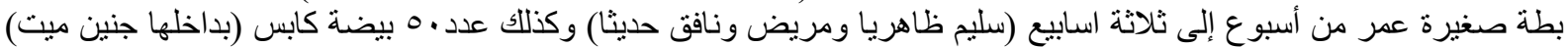

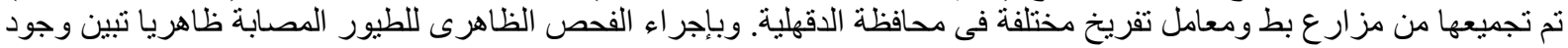

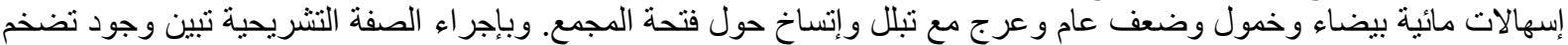

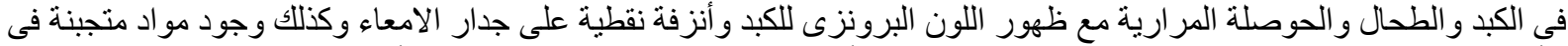

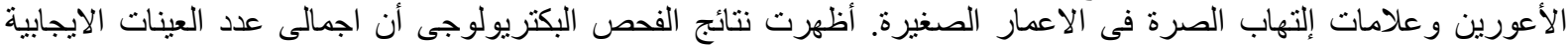

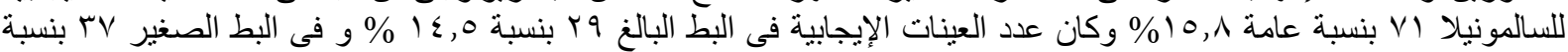

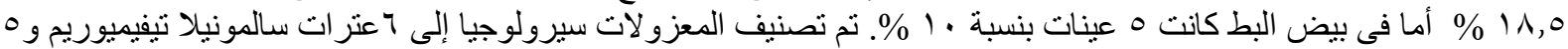

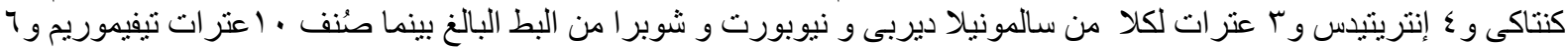

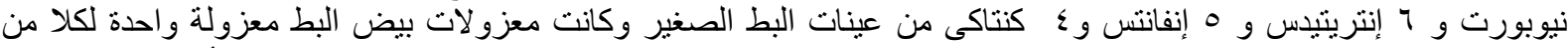

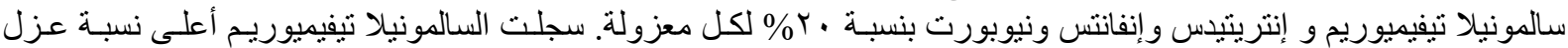

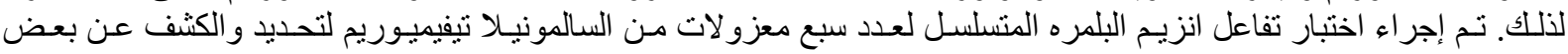

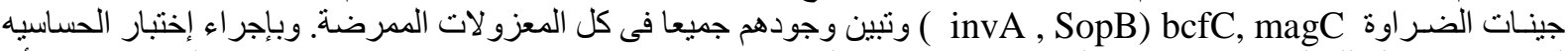

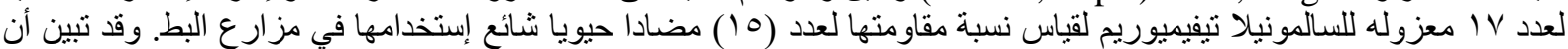

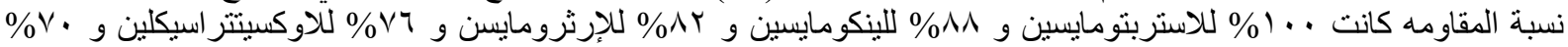

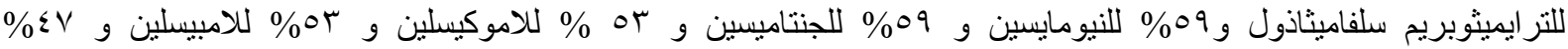

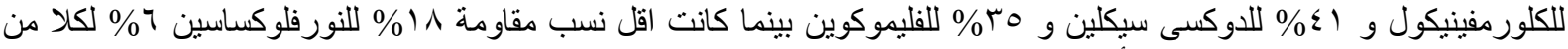

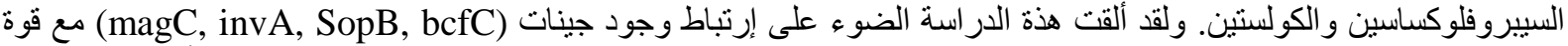

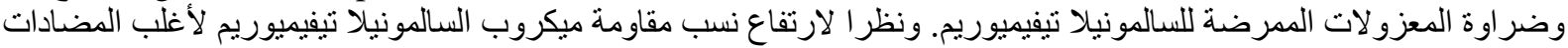

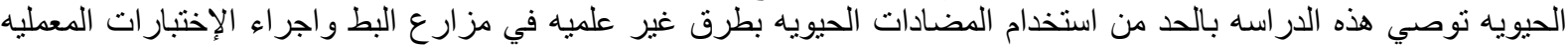

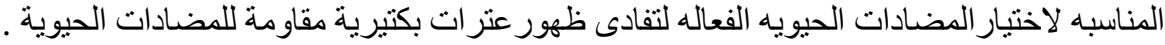

